\title{
Article \\ Effect of Phosphorus Application on Arsenic Species Accumulation and Co-Deposition of Polyphenols in Rice Grain: Phyto and Food Safety Evaluation
}

\author{
Arghya Chattopadhyay ${ }^{1,+}$, Anand Prakash Singh ${ }^{1}$, Deepak Kasote ${ }^{2, *}++^{\mathbb{C}}$, Indrajit Sen ${ }^{2}$ and Ahmed Regina ${ }^{2, *}$ \\ 1 Department of Soil Science \& Agricultural Chemistry, Institute of Agricultural Sciences, Banaras Hindu \\ University, Varanasi 221005, India; arghya.chattopadhyay1@bhu.ac.in (A.C.); dean_ag@bhu.ac.in (A.P.S.) \\ 2 Centre of Excellence in Rice Value Addition (CERVA), International Rice Research Institute (IRRI)—South \\ Asia Regional Centre (ISARC), Varanasi 221106, India; indraorg@gmail.com \\ * Correspondence: d.kasote@irri.org (D.K.); a.regina@irri.org (A.R.); Tel.: +91-542-2518900 \\ + These authors contributed equally to this work.
}

check for updates

Citation: Chattopadhyay, A.; Singh, A.P.; Kasote, D.; Sen, I.; Regina, A.

Effect of Phosphorus Application on Arsenic Species Accumulation and Co-Deposition of Polyphenols in Rice Grain: Phyto and Food Safety Evaluation. Plants 2021, 10, 281. https://doi.org/10.3390/plants100 20281

Received: 19 November 2020 Accepted: 29 December 2020 Published: 2 February 2021

Publisher's Note: MDPI stays neutral with regard to jurisdictional clai$\mathrm{ms}$ in published maps and institutional affiliations.

Copyright: (C) 2021 by the authors. Licensee MDPI, Basel, Switzerland. This article is an open access article distributed under the terms and conditions of the Creative Commons Attribution (CC BY) license (https:// creativecommons.org/licenses/by/ $4.0 /)$.

\begin{abstract}
The present study was aimed at exploring the effect of soil application of different concentrations of orthophosphate $(\mathrm{P})\left(0,10,20,30\right.$, and $\left.40 \mathrm{mg} \mathrm{kg}^{-1}\right)$ on rice agronomic and yield parameters, arsenic (As) species accumulation, and polyphenol levels in the grain of rice grown under As spiked soil (10 mg kg-1). The contents of As species (As(V), As (III), MMA and DMA) and polyphenols in rice grain samples were estimated using LC-ICP-MS and LC-MS/MS, respectively. P treatments significantly reduced the toxic effects of As on agronomic parameters such as root weight and length, shoot and spike length, straw, and grain yield. Among the treatments studied, only the treatment of $30 \mathrm{mg} \mathrm{kg}^{-1} \mathrm{P}$ helps to decrease the elevated levels of As (V), As (III), and DMA in rice grains due to As application. The study revealed that $30 \mathrm{mg} \mathrm{kg}^{-1}$ was the optimal P application amount to minimize AS accumulation in rice grains and As-linked toxicity on agronomic parameters and chlorophyll biosynthesis. Furthermore, the levels of trans-ferulic acid, chlorogenic acid, caffeic acid, and apigenin-7-glucoside increased in response to accumulation of As in the rice grain. In conclusion, the precise use of phosphorus may help to mitigate arsenic linked phytotoxicity and enhance the food safety aspect of rice grain.
\end{abstract}

Keywords: arsenic speciation; LC-ICP-MS; LC-MS/MS; phosphorus; phenolics; flavonoids; rice; toxicity

\section{Introduction}

Arsenic (As) is a non-essential element for plants and humans, and it has been found to exhibit considerable toxicity upon excess accumulation [1]. Source of As in soil may be geogenic or anthropogenic [2,3]. Irrigation with As contaminated water further adds the risk of soil contamination in crop fields [4,5]. The elevated level of As in soil is found to influence the yield of crops [6]. Along with a decrease in crop yield, the occurrence of As in the food chain is also a primary concern, considering overall food safety.

Rice, the staple food for half of the world population, is prone to accumulating a considerable amount of inorganic As when grown in As contaminated soils [7]. Flooding of paddy soil leads to reductive dissolution and mobilization of land-bound As into the plant parts [8]. As concentrations in rice grains, husks, stalks, and roots are found to have a positive correlation with their levels in soil and irrigation water [9]. In rice, As is present in several forms, which are mutually interchangeable [1]. The probable toxicity of these forms is in the order of AsH3 > Arsenite (As (III)) > Arsenate (As (V)) > MMA (monomethyl arsonic acid) > DMA (dimethyl arsinic acid) [10]. The rice grain accumulates considerably higher levels of inorganic As than other food grains [11]. The concentration of As above $200 \mu \mathrm{g} \mathrm{Kg}^{-1}$ in polished rice may pose a significant health risk in humans [12]. 
The exposure of As has an adverse impact on the morphological (reduction in leaf number and chlorosis), physiological (inhibition in overall growth processes, photosynthetic efficiency, and biomass accumulation), and biochemical (oxidative stress and damage of biomolecules) responses of plants [13]. As (V) generates toxicity through the replacement of inorganic phosphorous in the key biochemical processes, while As (III) inhibits the enzymatic action by binding with the sulfhydryl groups in proteins that leads to membrane deterioration and subsequently cell death [13,14]. In plants, absorbed As (V) is converted into As (III) in some parts by an enzyme arsenate reductase. As (III) is stored in the vacuole and is further detoxified [15]. Both As (V) and As (III), including their conversion, are also responsible for the production of reactive oxygen species (ROS), which causes oxidative damage $[13,16]$. Several agronomic mitigation strategies such as cultivating rice under aerobic conditions, intermittent flooding, use of As-hyperaccumulating plant species in rotation, or in combination and alternate wetting and drying conditions are found to be useful in reducing As input and bioavailability in rice [17]. Moreover, the applications of high doses of phosphorus, iron, and silicon fertilizers are found to reduce the toxic effects of As, significantly [17]. However, in chickpea, $\mathrm{Pi}$ was found to increase the uptake of As from soil [18]. Some studies showed that a high amount of Pi application in As rich soil could induce As linked toxicity in plants $[19,20]$.

Plants have effective enzymatic and non-enzymatic antioxidant protection mechanisms to attenuate the toxic effects of ROS [21]. Enzymatic defense systems comprise superoxide dismutase, glutathione peroxidase, catalase, and glutathione reductase. In contrast, the non-enzymatic defense systems include low molecular weight antioxidants such as ascorbic acid, carotenoids, glutathione, proline, phenolic acids, flavonoids, and high molecular weight secondary metabolites like tannins [21,22]. The exposure of As has been reported to disturb the enzymatic antioxidant defense system and decrease non-enzymatic antioxidant ascorbate in the rice seedlings [23]. Recently, treatments with inorganic (As (III), As (V)) and organic (dimethylarsinic acid-DMA) As forms to Acer platanoides seedlings were induced phenolic contents in the leaves, which was dependent on the As species and their concentrations $[1,24]$. However, there is limited insight on the impact of the accumulation of As species in rice grain on the profiles of phenolic acids and flavonoids.

This study aimed to explore the As toxicity mitigation potential of phosphorus through understanding the effects of different concentrations of orthophosphate (P) $\left(10-40 \mathrm{mg} \mathrm{kg}^{-1}\right)$ application in soil on As species accumulation in the grain of rice grown under As spiked soil $\left(10 \mathrm{mg} \mathrm{kg}^{-1}\right)$. The study also investigated the grain polyphenols profiles of rice grown in As and P spiked soil to identify metabolite markers to be used in breeding for low arsenic accumulating rice. This study enabled determining the optimal $\mathrm{P}$ application level for minimizing the As toxicity in rice.

\section{Results}

\subsection{Agronomic Parameters}

The As, and combined As and $P$ treatments showed a considerable impact on various agronomic parameters of rice (Table 1). The As treatment (T0) significantly decreased total chlorophyll, root weight and length, shoot and panicle length, straw, and grain yield compared to untreated control (Table 1). A reduction of nearly 50\% in grain yield and 39\% in straw yield was caused by As treatment (T0) when compared with the control group (C) plants. Moreover, among the studied combined As and P treatments, only treatment T3 significantly alleviated As linked reduction in total chlorophyll content (Table 1). 


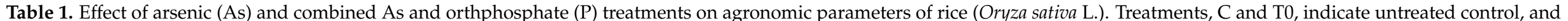

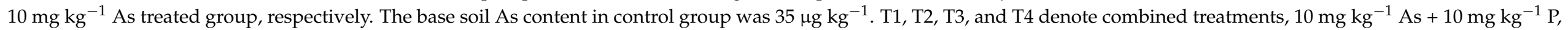

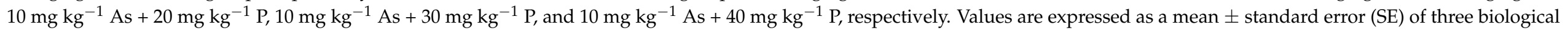
replicates. Significant differences $(p<0.05)$ among different treatments are shown by different letters.

\begin{tabular}{|c|c|c|c|c|c|c|c|c|}
\hline & $\begin{array}{l}\text { Total Chlorophyll } \\
\text { (mg g }{ }^{-1} \text { F.W.) }\end{array}$ & $\begin{array}{l}\text { Shoot Length } \\
\text { (cm) }\end{array}$ & $\begin{array}{l}\text { Root Weight } \\
\text { (g) }\end{array}$ & $\begin{array}{l}\text { Root Length } \\
\text { (cm) }\end{array}$ & $\begin{array}{l}\text { Spike Length } \\
\text { (cm) }\end{array}$ & $\begin{array}{c}\text { Test Weight } \\
\text { (g) }\end{array}$ & $\begin{array}{l}\text { Grain Yield } \\
\left(\mathrm{g} \mathrm{pot}^{-1}\right)\end{array}$ & $\begin{array}{l}\text { Straw Yield } \\
\left(\operatorname{g~pot}^{-1}\right)\end{array}$ \\
\hline $\mathrm{C}$ & $2.48 \pm 0.11 \mathrm{a}$ & $87.8 \pm 1.15 \mathrm{a}$ & $42.1 \pm 1.79 \mathrm{a}$ & $27.5 \pm 2.18 \mathrm{ab}$ & $28.3 \pm 0.79 \mathrm{a}$ & $20.4 \pm 0.29 \mathrm{a}$ & $20.1 \pm 0.66 \mathrm{a}$ & $44.6 \pm 1.43 \mathrm{a}$ \\
\hline T0 & $1.83 \pm 0.11 c$ & $77.2 \pm 1.07 \mathrm{~b}$ & $22.1 \pm 1.07 \mathrm{c}$ & $18.3 \pm 1.30 \mathrm{c}$ & $22.0 \pm 0.48 \mathrm{~d}$ & $20.0 \pm 0.15 \mathrm{a}$ & $10.2 \pm 0.89 c$ & $32.0 \pm 1.10 \mathrm{~d}$ \\
\hline $\mathrm{T} 2$ & $2.14 \pm 0.14 \mathrm{a}-\mathrm{c}$ & $85.7 \pm 1.87 \mathrm{a}$ & $36.7 \pm 1.66 \mathrm{ab}$ & $27.0 \pm 1.30 \mathrm{ab}$ & $26.4 \pm 0.94 \mathrm{ab}$ & $20.6 \pm 0.32 \mathrm{a}$ & $17.3 \pm 0.51 b$ & $35.9 \pm 1.05 \mathrm{~cd}$ \\
\hline $\mathrm{T} 3$ & $2.40 \pm 0.12 \mathrm{ab}$ & $85.4 \pm 1.30 \mathrm{a}$ & $41.2 \pm 2.09 \mathrm{a}$ & $29.7 \pm 1.13 \mathrm{a}$ & $27.5 \pm 0.53 \mathrm{ab}$ & $20.7 \pm 0.15 a$ & $15.7 \pm 0.52 \mathrm{~b}$ & $41.9 \pm 1.70 \mathrm{ab}$ \\
\hline $\mathrm{T} 4$ & $1.86 \pm 0.17 c$ & $83.1 \pm 1.44 \mathrm{a}$ & $37.7 \pm 1.76 \mathrm{ab}$ & $27.0 \pm 1.73 \mathrm{ab}$ & $25.5 \pm 0.87 b c$ & $20.1 \pm 0.15 a$ & $16.7 \pm 1.20 \mathrm{~b}$ & $40.0 \pm 1.23 b c$ \\
\hline
\end{tabular}




\subsection{Arsenic Species Distribution, Accumulation and Phosphorus Content in Rice Grain}

Four As species, namely As (III), As (V), MMA, and DMA, were detected in rice grain (Table 2). Among them, the concentration of MMA was very low, and in some samples, it was below the detection limit. The As application (T0) significantly $(p<0.05)$ increased the levels of As species in grains. Although the applied As was in the form of $\mathrm{As}(\mathrm{V})$, we detected a significant increase in all four species in rice grain, indicating the As species conversion occurring in rice. Plants those received $10 \mathrm{mg} \mathrm{kg}^{-1} \mathrm{As}+$ $30 \mathrm{mg} \mathrm{kg}^{-1} \mathrm{P}$ (T3 treatment) significantly decreased the elevated concentrations of As (V), As (III), and DMA in rice grains due to the alone As application in soil (Table 2). This finding underlines the critical role of the $\mathrm{P}$ application concentration in the paddy field to minimize As accumulation in the rice grain. The T3 $\left(10 \mathrm{mg} \mathrm{kg}^{-1} \mathrm{As}+30 \mathrm{mg} \mathrm{kg}^{-1} \mathrm{P}\right)$ and $\mathrm{T} 4\left(10 \mathrm{mg} \mathrm{kg}^{-1} \mathrm{As}+40 \mathrm{mg} \mathrm{kg}^{-1} \mathrm{P}\right)$ treatments showed a significant increase in rice grain $\mathrm{P}$ content, compared with P-deficient $\mathrm{C}$ and $\mathrm{T} 0$ groups. This finding demonstrated that a considerable amount of $\mathrm{P}$ was transported to the grain at or above $30 \mathrm{mg} \mathrm{kg}^{-1}$ of $\mathrm{P}$ application in soil.

Table 2. The contents of arsenic (As) species and orthphosphate (P) in rice (Oryza sativa L.) grain after exposure of As and combined As and P treatments. Treatments, $\mathrm{C}$ and T0, indicate untreated control, and $10 \mathrm{mg} \mathrm{kg}^{-1} \mathrm{As}$ treated group, respectively. The base soil As content in control group was $35 \mu \mathrm{g} \mathrm{kg}{ }^{-1}$. T1, T2, T3, and T4 denote combined treatments, $10 \mathrm{mg} \mathrm{kg}^{-1} \mathrm{As}+10 \mathrm{mg} \mathrm{kg}^{-1} \mathrm{P}, 10 \mathrm{mg} \mathrm{kg}^{-1} \mathrm{As}+20 \mathrm{mg} \mathrm{kg}^{-1} \mathrm{P}, 10 \mathrm{mg} \mathrm{kg}^{-1} \mathrm{As}+30 \mathrm{mg} \mathrm{kg}^{-1} \mathrm{P}$, and $10 \mathrm{mg} \mathrm{kg}^{-1} \mathrm{As}+$ $40 \mathrm{mg} \mathrm{kg}^{-1} \mathrm{P}$, respectively. Results were expressed as a mean \pm standard error (SE) of three biological and two technical replicates per sample. Significant differences $(p<0.05)$ among different treatments are shown by different letters. As (III), arsenite; As (V), arsenate; MMA, monomethyl arsonic acid; DMA, dimethyl arsenic acid.

\begin{tabular}{ccccccc}
\hline \multirow{2}{*}{ Treatments } & \multicolumn{3}{c}{ Concentration in $\mu \mathbf{~ K g}^{-\mathbf{1}}$} & \multicolumn{2}{c}{$\begin{array}{c}\text { Phosphorus } \\
\text { (g Kg }\end{array}$} \\
\cline { 2 - 6 } & As (V) & MMA & As (III) & DMA & Total As & \\
\hline C & $60.1 \pm 8.28 \mathrm{~d}$ & nd & $23.3 \pm 2.91 \mathrm{~d}$ & $10.0 \pm 1.59 \mathrm{e}$ & $93.4 \pm 12.76 \mathrm{e}$ & $2.87 \pm 0.20 \mathrm{~d}$ \\
T0 & $185 \pm 17.2 \mathrm{a}$ & $1.95 \pm 0.03 \mathrm{~b}$ & $130 \pm 9.41 \mathrm{a}$ & $363 \pm 2.96 \mathrm{~b}$ & $679 \pm 23.6 \mathrm{~b}$ & $3.07 \pm 0.20 \mathrm{~cd}$ \\
T1 & $125 \pm 13.4 \mathrm{bc}$ & $6.53 \pm 0.08 \mathrm{a}$ & $104 \pm 7.56 \mathrm{a}-\mathrm{c}$ & $543 \pm 3.34 \mathrm{a}$ & $778 \pm 11.2 \mathrm{a}$ & $3.33 \pm 0.24 \mathrm{~b}-\mathrm{d}$ \\
T2 & $120 \pm 1.54 \mathrm{bc}$ & $0.46 \pm 0.13 \mathrm{c}$ & $96 \pm 17.8 \mathrm{bc}$ & $370 \pm 19.6 \mathrm{~b}$ & $586 \pm 35.9 \mathrm{c}$ & $3.80 \pm 0.24 \mathrm{a}-\mathrm{c}$ \\
T3 & $96.2 \pm 7.96 \mathrm{c}$ & nd & $83 \pm 9.12 \mathrm{c}$ & $89.7 \pm 1.95 \mathrm{~d}$ & $269 \pm 1.65 \mathrm{~d}$ & $4.10 \pm 0.29 \mathrm{ab}$ \\
T4 & $137 \pm 8.69 \mathrm{~b}$ & $0.38 \pm 0.04 \mathrm{c}$ & $119 \pm 2.69 \mathrm{ab}$ & $295 \pm 8.69 \mathrm{c}$ & $551 \pm 5.24 \mathrm{c}$ & $4.30 \pm 0.27 \mathrm{a}$ \\
\hline
\end{tabular}

\subsection{Phenolic Acids and Flavonoids Contents in Rice Grain}

Amongst the nine phenolic acids analyzed, As treatment (T0) significantly increased $(p<0.05)$ the levels of chlorogenic acid (CGA), caffeic acid (CA), and trans-ferulic acid (TFA) compared with the untreated control (C) (Table 3). No significant changes were found in the levels of gallic acid (GA), 4-hydroxybenzoic acid (4-HBA), protocatechuic acid (PA), $P$-coumaric acid ( $p-C A$ ), and vanillic acid (VA) in rice grains after As treatment (Table 3 ). The combined As and P treatments (T1 to T4) also followed the same trend in the case of CGA (Table 3). As-associated increased CA was significantly decreased with the application of P treatments, T1, T2 and T3 compared with T0 treatment (Table 3). Interestingly, Aslinked decreased sinapic acid (SA) level was increased in treatments, T1 and T3. Results of correlation studies showed that TFA and SA had the highest positive correction $(r=0.73$, and $r=0.69$, respectively) with MMA. Similarly, TFA and SA were showing moderate positive correlation with DMA. Interestingly, SA had negative correlation with As (V) and As (III) (Figure 1A,B). Among other phenolic acids, CGA and CA showed moderate positive correlation with As(V) (Figure 1A). 4-HBA showed a negative correlation with all As species. However, the content of HBA among the various treatments studied was not statistically significant. 
Table 3. Phenolic acid profiles of rice grain samples after exposure of different Arsenic (As) and combined As and orthphosphate $(\mathrm{P})$ treatments. Treatments, $\mathrm{C}$ and T0, indicate untreated control, and $10 \mathrm{mg} \mathrm{kg}^{-1} \mathrm{As}_{\text {treated group, }}$ respectively. The base soil As content in control group was $35 \mu \mathrm{g} \mathrm{kg}{ }^{-1}$. T1, T2, T3, and T4 denote combined treatments, $10 \mathrm{mg} \mathrm{kg}^{-1} \mathrm{As}+10 \mathrm{mg} \mathrm{kg}^{-1} \mathrm{P}, 10 \mathrm{mg} \mathrm{kg}^{-1} \mathrm{As}+20 \mathrm{mg} \mathrm{kg}^{-1} \mathrm{P}, 10 \mathrm{mg} \mathrm{kg}^{-1} \mathrm{As}+30 \mathrm{mg} \mathrm{kg}^{-1} \mathrm{P}$, and $10 \mathrm{mg} \mathrm{kg}^{-1} \mathrm{As}+$ $40 \mathrm{mg} \mathrm{kg}^{-1} \mathrm{P}$, respectively. All values are expressed as a mean \pm standard error (SE) of three biological and two technical replicates per sample. Significant differences $(p<0.05)$ among different treatments are shown by different letters.

\begin{tabular}{|c|c|c|c|c|c|c|c|c|c|}
\hline \multirow{2}{*}{ Treatments - } & \multicolumn{9}{|c|}{ Concentration in $\mathrm{mg} \mathrm{Kg}^{-1}$} \\
\hline & GA & PA & 4-HBA & CGA & VA & CA & p-CA & TFA & SA \\
\hline \multirow{2}{*}{ C } & $0.54 \pm$ & $0.32 \pm$ & $0.94 \pm$ & $0.06 \pm$ & $0.82 \pm$ & $1.06 \pm$ & $1.02 \pm$ & $2.70 \pm$ & $0.38 \pm$ \\
\hline & $0.01 \mathrm{a}$ & $0.10 \mathrm{a}$ & $0.15 \mathrm{a}$ & $0.02 \mathrm{~b}$ & $0.06 \mathrm{ab}$ & $0.57 \mathrm{bc}$ & $0.15 \mathrm{a}$ & $0.72 \mathrm{c}$ & $0.01 \mathrm{c}$ \\
\hline \multirow{2}{*}{ T0 } & $0.56 \pm$ & $0.34 \pm$ & $0.60 \pm$ & $0.09 \pm$ & $0.80 \pm$ & $6.37 \pm$ & $1.38 \pm$ & $4.20 \pm$ & $0.29 \pm$ \\
\hline & $0.03 \mathrm{a}$ & $0.07 \mathrm{a}$ & $0.12 \mathrm{a}$ & $0.01 \mathrm{a}$ & $0.20 \mathrm{ab}$ & $0.59 \mathrm{a}$ & $0.21 \mathrm{a}$ & $0.32 \mathrm{~b}$ & $0.03 c$ \\
\hline \multirow{2}{*}{$\mathrm{T} 1$} & $0.60 \pm$ & $0.25 \pm$ & $0.79 \pm$ & $0.08 \pm$ & $0.65 \pm$ & $0.24 \pm$ & $1.26 \pm$ & $5.80 \pm$ & $0.71 \pm$ \\
\hline & $0.04 \mathrm{a}$ & $0.02 \mathrm{a}$ & $0.20 \mathrm{a}$ & $0.01 \mathrm{ab}$ & $0.20 \mathrm{~b}$ & $0.02 \mathrm{c}$ & $0.15 \mathrm{a}$ & $0.03 \mathrm{a}$ & $0.03 \mathrm{a}$ \\
\hline \multirow{2}{*}{$\mathrm{T} 2$} & $0.53 \pm$ & $0.32 \pm$ & $1.01 \pm$ & $0.08 \pm$ & $1.42 \pm$ & $4.94 \pm$ & $1.04 \pm$ & $3.23 \pm$ & $0.53 \pm$ \\
\hline & $0.02 \mathrm{a}$ & $0.09 \mathrm{a}$ & $0.25 \mathrm{a}$ & $0.01 \mathrm{ab}$ & $0.39 \mathrm{a}$ & $1.17 \mathrm{a}$ & $0.11 \mathrm{a}$ & $0.63 \mathrm{bc}$ & $0.01 \mathrm{~b}$ \\
\hline \multirow{2}{*}{ T3 } & $0.56 \pm$ & $0.23 \pm$ & $0.69 \pm$ & $0.08 \pm$ & $0.66 \pm$ & $1.04 \pm$ & $1.22 \pm$ & $4.10 \pm$ & $0.37 \pm$ \\
\hline & $0.04 \mathrm{a}$ & $0.03 \mathrm{a}$ & $0.13 \mathrm{a}$ & $0.01 \mathrm{ab}$ & $0.08 \mathrm{~b}$ & $0.58 \mathrm{bc}$ & $0.08 \mathrm{a}$ & $0.27 \mathrm{~b}$ & $0.07 \mathrm{c}$ \\
\hline \multirow{2}{*}{$\mathrm{T} 4$} & $0.54 \pm$ & $0.34 \pm$ & $0.81 \pm$ & $0.08 \pm$ & $0.66 \pm$ & $2.64 \pm$ & $1.18 \pm$ & $3.25 \pm$ & $0.27 \pm$ \\
\hline & $0.01 \mathrm{a}$ & $0.06 \mathrm{a}$ & $0.18 \mathrm{a}$ & $0.01 \mathrm{ab}$ & $0.03 \mathrm{~b}$ & $0.92 b$ & $0.09 \mathrm{a}$ & $0.15 b c$ & $0.04 \mathrm{c}$ \\
\hline
\end{tabular}

(A)
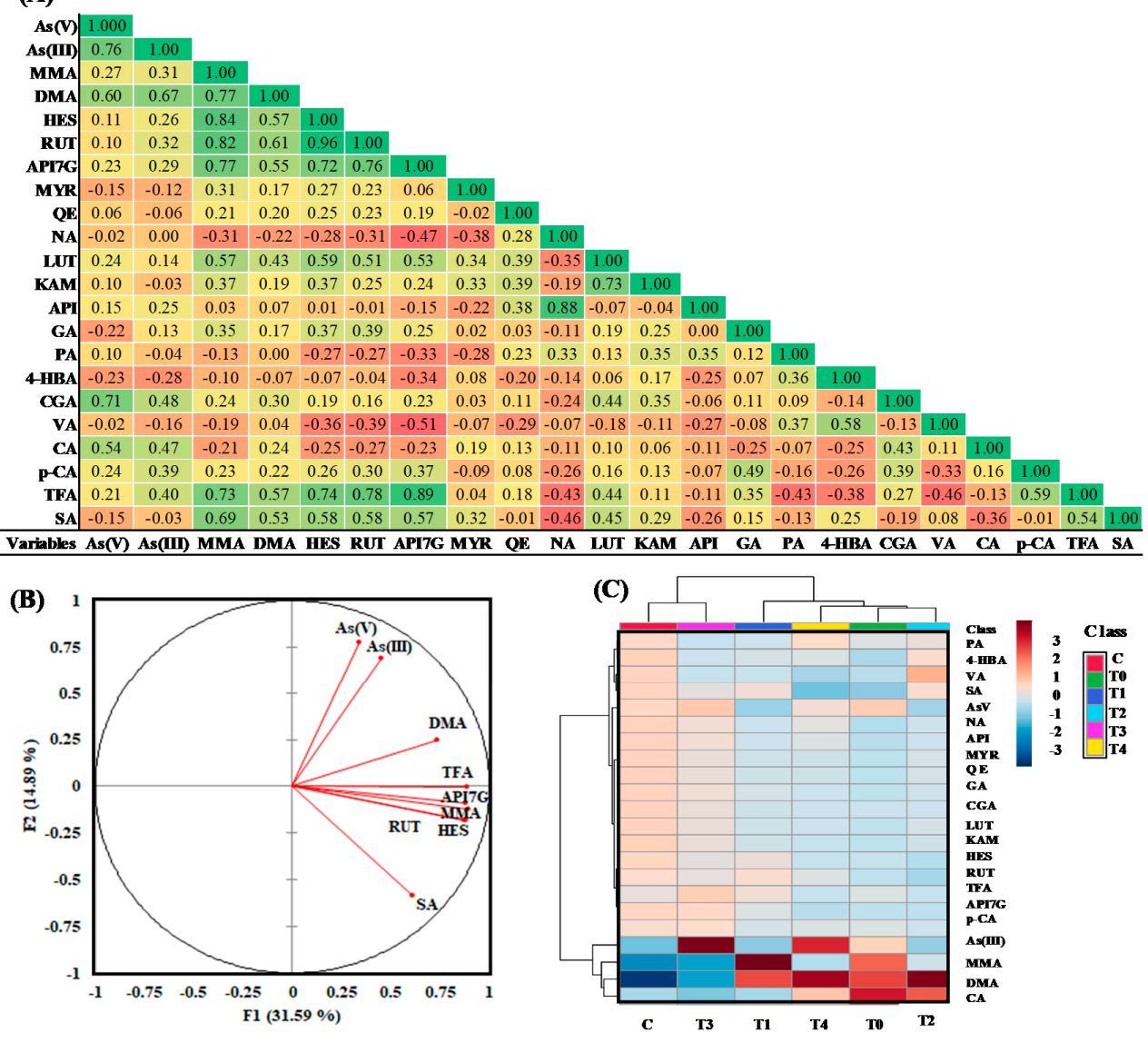

Figure 1. (A) Correlation analysis between arsenic species, phenolics, and flavonoids of rice grains. (B) Principal component analysis (PCA) biplot plot and (C) correlation heatmap, distinguishes different treatment groups based on arsenic species, phenolics, and flavonoids contents of rice grain. Treatments, C and T0, indicate untreated control, and $10 \mathrm{mg} \mathrm{kg}^{-1} \mathrm{As}$ treated group, respectively. T1, T2, T3, and T4 denote combined treatments, $10 \mathrm{mg} \mathrm{kg}^{-1} \mathrm{As}+10 \mathrm{mg} \mathrm{kg}^{-1} \mathrm{P}, 10 \mathrm{mg} \mathrm{kg}^{-1} \mathrm{As}$ $+20 \mathrm{mg} \mathrm{kg}^{-1} \mathrm{P}, 10 \mathrm{mg} \mathrm{kg}^{-1} \mathrm{As}+30 \mathrm{mg} \mathrm{kg}^{-1} \mathrm{P}$, and $10 \mathrm{mg} \mathrm{kg}^{-1} \mathrm{As}+40 \mathrm{mg} \mathrm{kg}^{-1} \mathrm{P}$, respectively. 
In addition to phenolic acids, the effects of above different $\mathrm{P}$ treatments on flavonoid profiles of rice grain were also studied. Among the nine flavonoids studied, the level of the only apigenin-7-glucoside (API7G) significantly $(p<0.05)$ elevated upon As exposure compared with untreated control (Table 4). The treatment T1, which received $10 \mathrm{mg} \mathrm{kg}^{-1}$ of $P$ and As (treatment T1), significantly increased the levels of hesperidin (HES), rutin (RUT), and API7G in rice grain compared with $\mathrm{T} 0$ and $\mathrm{C}$ groups. However, the higher dose of $\mathrm{P}$ application had no further significant impact on HES, RUT, and API7G levels compared with $\mathrm{T} 0$ and $\mathrm{C}$ treatments. The results of correlation studies showed that HES, RUT, and API7G had the highest positive correction $(r=0.84, r=0.82$, and $r=0.77$, respectively) with MMA (Figure 1A). Moreover, HES, RUT, and API7G had moderate positive correction with DMA (Figure 1A). Thus, similar to TFA, API7G could also deposit in response to accumulation of organic As species.

Table 4. Flavonoid profiles of rice grain samples after exposure of different Arsenic (As) and combined As and orthphosphate (P) treatments. Treatments, $\mathrm{C}$ and T0, indicate untreated control, and $10 \mathrm{mg} \mathrm{kg}^{-1}$ As treated group, respectively. The base soil As content in control group was $35 \mu \mathrm{g} \mathrm{kg}{ }^{-1}$. T1, T2, T3, and T4 denote combined treatments, $10 \mathrm{mg} \mathrm{kg}^{-1}$ As

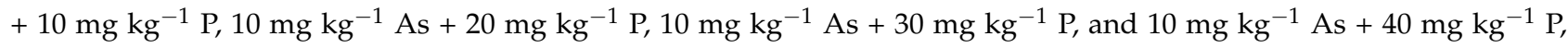
respectively. All values are expressed as a mean \pm standard error (SE) of three biological and two technical replicates per sample. Significantly differences $(p<0.05)$ among different treatments are shown by different letters.

\begin{tabular}{|c|c|c|c|c|c|c|c|c|c|}
\hline \multirow{2}{*}{ Treatments - } & \multicolumn{9}{|c|}{ Concentration in $\mathrm{mg} \mathrm{Kg}^{-1}$} \\
\hline & HES & RUT & API7G & MYR & QE & NA & LUT & KAM & API \\
\hline $\mathrm{C}$ & $\begin{array}{c}0.16 \pm \\
0.01 \mathrm{~b}\end{array}$ & $0.11 \pm$ & $0.06 \pm$ & $1.74 \pm$ & $0.57 \pm$ & $0.13 \pm$ & $0.25 \pm$ & $0.15 \pm$ & $0.23 \pm$ \\
\hline \multirow{2}{*}{ T0 } & $0.19 \pm$ & $0.14 \pm$ & $0.08 \pm$ & $1.73 \pm$ & $0.57 \pm$ & $0.12 \pm$ & $0.26 \pm$ & $0.16 \pm$ & $0.24 \pm$ \\
\hline & $0.01 \mathrm{~b}$ & $0.01 \mathrm{~b}$ & $0.01 \mathrm{~b}$ & $0.01 \mathrm{ab}$ & $0.01 \mathrm{a}$ & $0.01 \mathrm{~b}$ & $0.01 \mathrm{a}$ & $0.01 \mathrm{a}$ & $0.01 \mathrm{~b}$ \\
\hline \multirow{2}{*}{$\mathrm{T} 1$} & $0.29 \pm$ & $0.26 \pm$ & $0.09 \pm$ & $1.73 \pm$ & $0.57 \pm$ & $0.12 \pm$ & $0.26 \pm$ & $0.15 \pm$ & $0.24 \pm$ \\
\hline & $0.03 \mathrm{a}$ & $0.03 \mathrm{a}$ & $0.01 \mathrm{a}$ & $0.01 \mathrm{a}$ & $0.01 \mathrm{a}$ & $0.01 \mathrm{~b}$ & $0.01 \mathrm{a}$ & $0.01 \mathrm{ab}$ & $0.01 \mathrm{ab}$ \\
\hline \multirow{2}{*}{$\mathrm{T} 2$} & $0.14 \pm$ & $0.11 \pm$ & $0.07 \pm$ & $1.73 \pm$ & $0.57 \pm$ & $0.12 \pm$ & $0.25 \pm$ & $0.15 \pm$ & $0.23 \pm$ \\
\hline & $0.02 \mathrm{~b}$ & $0.02 \mathrm{~b}$ & $0.01 \mathrm{bc}$ & $0.01 \mathrm{ab}$ & $0.01 \mathrm{a}$ & $0.01 \mathrm{~b}$ & $0.01 \mathrm{ab}$ & $0.01 \mathrm{ab}$ & $0.01 \mathrm{~b}$ \\
\hline \multirow{2}{*}{ T3 } & $0.16 \pm$ & $0.13 \pm$ & $0.08 \pm$ & $1.71 \pm$ & $0.57 \pm$ & $0.13 \pm$ & $0.25 \pm$ & $0.15 \pm$ & $0.24 \pm$ \\
\hline & $0.01 \mathrm{~b}$ & $0.01 \mathrm{~b}$ & $0.01 \mathrm{~b}$ & $0.01 \mathrm{~b}$ & $0.01 \mathrm{a}$ & $0.02 \mathrm{ab}$ & $0.01 \mathrm{~b}$ & $0.01 \mathrm{ab}$ & $0.01 \mathrm{ab}$ \\
\hline \multirow{2}{*}{$\mathrm{T} 4$} & $0.17 \pm$ & $0.15 \pm$ & $0.07 \pm$ & $1.72 \pm$ & $0.57 \pm$ & $0.14 \pm$ & $0.25 \pm$ & $0.14 \pm$ & $0.26 \pm$ \\
\hline & $0.02 \mathrm{~b}$ & $0.02 \mathrm{~b}$ & $0.01 \mathrm{bc}$ & $0.01 \mathrm{ab}$ & $0.01 \mathrm{a}$ & $0.01 \mathrm{a}$ & $0.01 \mathrm{~b}$ & $0.01 \mathrm{~b}$ & $0.02 \mathrm{a}$ \\
\hline
\end{tabular}

The data were further subjected to multivariant analysis to understand the co-deposition relationship between phenolic compounds and different species of As in rice grain in response to soil application of As and combined As and P treatments. The principal component of analysis (PCA) biplot was constructed to display the relationship among the studied variables (Figure 1B). In PCA biplot, vectors are representing the active variables, and angle between two vectors demonstrating correlation among them. As observed in the correlation matrix study, TFA, HES, RUT, and API7G had a strong positive correlation with MMA. Similarly, SA was also showing positive correlation with MMA and DMA, and negative correlation with As (V) and As (III). Dendrogram from the hierarchical clustering analysis (HCA) was also generated to demonstrate how the studied treatments are grouped, based on the correlation between quantified arsenic species, phenolics, and flavonoids (Figure 1C). We found that all the studied treatments were classified into two main groups. Interestingly, treatment groups, $\mathrm{C}$ and $\mathrm{T} 3$ were falling under the same cluster, indicating $\mathrm{P}$ application at concentration $30 \mathrm{mg} \mathrm{kg}^{-1}$ could reduce the accumulation of As in the rice grain. The clustering of all other treatments in dendrogram was further demonstrating $\mathrm{P}$ application at a concentration above and below $30 \mathrm{mg} \mathrm{kg}^{-1}$ favors As accumulation in rice grain. We performed a supervised dimension reduction analysis, partial least squares discriminant analysis (PLS-DA), to visualize the clustering pattern among various studied treatments, based on arsenic species, phenolics, and flavonoids contents of rice grain (Figure 2A). PLS- DA scores plot explained $81.2 \%$ of the total variability of the 
data (Figure 2A), which is sufficient to interpret the complex interactions existing between treatments and their effects on arsenic species, phenolics, and flavonoids contents of rice grain [25].

(A)

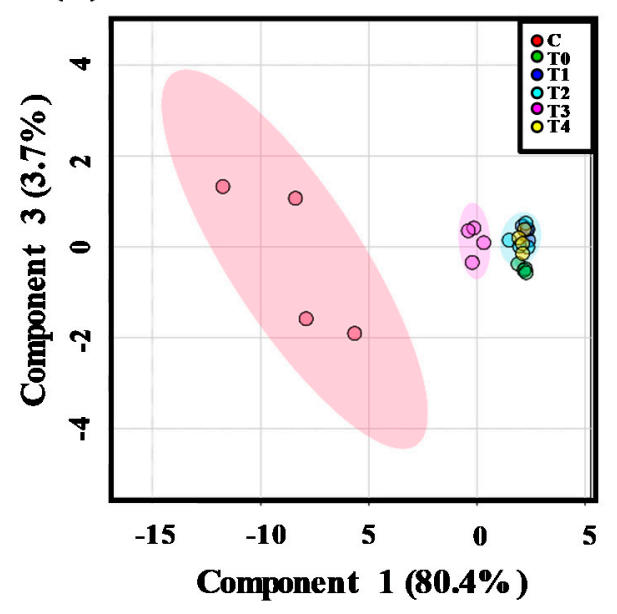

(B)

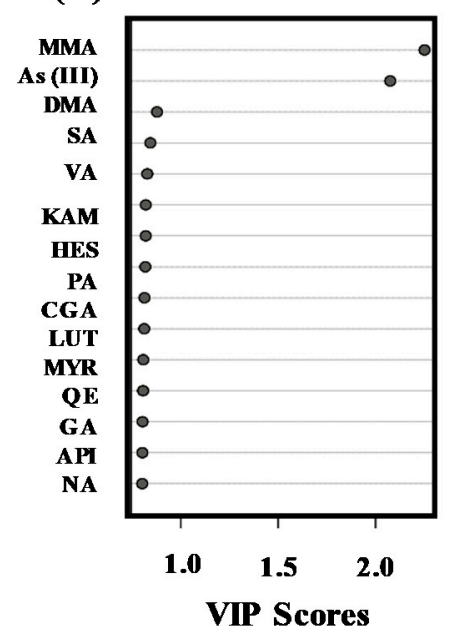

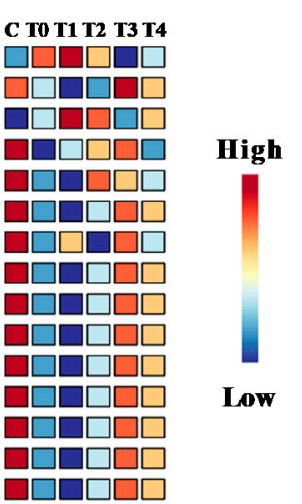

Figure 2. (A) Partial least squares discriminant analysis (PLS-DA) scores plot. (B) Variable importance in projection (VIP) scores plot indicating the most discriminating arsenic species, phenolics and flavonoids in of rice grain samples before and after exposure of different Arsenic (As) and combined As and phosphate (P) treatments. Treatments, C and T0, indicate untreated control, and $10 \mathrm{mg} \mathrm{kg}^{-1}$ As treated group, respectively. T1, T2, T3, and T4 denote combined treatments, $10 \mathrm{mg}$ $\mathrm{kg}^{-1} \mathrm{As}+10 \mathrm{mg} \mathrm{kg}^{-1} \mathrm{P}, 10 \mathrm{mg} \mathrm{kg}^{-1} \mathrm{As}+20 \mathrm{mg} \mathrm{kg}^{-1} \mathrm{P}, 10 \mathrm{mg} \mathrm{kg}^{-1} \mathrm{As}+30 \mathrm{mg} \mathrm{kg}^{-1} \mathrm{P}$, and $10 \mathrm{mg} \mathrm{kg}^{-1} \mathrm{As}^{-4} 40 \mathrm{mg} \mathrm{kg}^{-1}$ $\mathrm{P}$, respectively.

In the PLS-DA scores plot, treatments C and T3 only formed distinct individual clusters, while all other treatments clustered together separately. The variable importance on projection (VIP) score plot was derived from the PLS-DA models to identify compounds responsible for clustering based on their VIP score [26]. VIP score plot showed MMA and As (III) had the highest magnitude of VIP scores, respectively (Figure 2B) among the quantified species of As, phenolic acids, and flavonoids. The results of these studies indicate that MMA and As (III) are the main As species of the rice grain, which are highly influenced in response to As and P application.

\section{Discussion}

The phytotoxicity of As is well known. The toxicity of As in plants varies with its speciation, plant species, and with other soil factors controlling As accumulation in plants [1]. In plants, As causes phytoxicity by increasing production of ROS either directly during conversion of As (V) to As (III) or indirectly via inactivation of the enzymatic antioxidants by binding to their thiol group [27]. External phosphate fertilization has been found to be useful in alleviating As toxicity in rice $[18,28]$. It has been proved that phosphorous is an important parameter in the paddy field for arsenic solubility in soil and its uptake by plants. Both As and phosphorous are the common members of the pnictides group and an analog of each other. Both of these elements have similar charged oxygen atoms, and thermochemical radii with a difference of only $4 \%$, including nearly identical acid dissociation constant values [29]. The competitive adsorption between phosphorous and arsenate occurs in the soil system which is controlled by soil $\mathrm{pH}$, redox potential, binding capacity, interconversion of As species, amounts of phosphorous addition, and rice genotypes [30]. Herein, soil with low available phosphorous $\left(10.3 \mathrm{mg} \mathrm{kg}^{-1}\right)$ was used to investigate the role and optimal amount of $\mathrm{P}$ in mitigating As induced toxicity in rice. The base As concentration in the soil was low $\left(35 \mu \mathrm{g} \mathrm{kg}^{-1}\right)$ and the phosphorous/As molar ratio was much higher (702.5). In the previous study, As associated toxicity has been reported for lower P/As molar ratios between 3 to 6 [31,32]. In this study, phosphorous / As molar 
ratio 2.5 was used to induce As toxicity and phosphorous / As molar ratio was further serial increased up to 12 by increasing $\mathrm{P}$ amount in the soil to investigate As toxicity mitigation potential of $\mathrm{P}$.

As is also reported to alter the chloroplast formation, including its partial degradation in bean plants [33]. In the chloroplast, As was found to inhibit tetrapyrrole biosynthesis [34]. Tetrapyrrole synthesis plays a major role in retrograde signaling and has a strong interaction with light signaling pathways that are important in chloroplast biogenesis [35]. Results of this study showed that only P treatment at $30 \mathrm{mg} \mathrm{Kg}^{-1}$ helps to reverse the adverse effect of As on chlorophyll biosynthesis in rice. Akin to our finding, moderate use of phosphorous fertilizer was found to be useful in improving chlorophyll content in Black Gram (Vigna mungo L.Var. PU19) affected by As toxicity [34].

As has adverse effects on the agronomic parameters of plants. In cucumber (Cucumis sativus L.), reduction in the xylem sap was observed under As stress, which leads to reduced shoot growth [36]. The toxicity of As on the root and shoot growth as well as on the rice grain yield have been reported in the previous studies [37,38]. Results of this study also demonstrated that As application had detrimental effect on rice growth parameters. In rice, that phosphorous treatment helps to reverse detrimental effect of As on growth, water content and carbohydrate metabolism of the rice seedlings [39]. Similar to these findings, our results also showed that the $\mathrm{P}$ treatments with As significantly improved the root weight and length, shoot and panicle length, straw, and grain yield. Moreover, in treatment T3 (10 $\left.\mathrm{mg} \mathrm{kg}^{-1} \mathrm{As}+30 \mathrm{mg} \mathrm{kg}^{-1} \mathrm{P}\right)$, the observed As content in grain was below the maximum permissible limit of $0.4 \mathrm{mg} \mathrm{kg}^{-1}$, indicating optimal application of $\mathrm{P}$ help to improve food safety aspect of rice.

In plants, the protonated neutral forms of As are transported through silicic acid pathway, and $\mathrm{As}(\mathrm{V})$ is transported via the phosphate transporter system $[40,41]$. Because of this, phosphorous and As(V) compete for uptake and translocation in many plants [41]. Interestingly, except $\mathrm{As}(\mathrm{V})$, phosphorous does not influence the uptake of other species of As, because of their different transport mechanisms [42]. As(III) is taken up by rice roots via silicic acid transporters [11]. Rice also uptakes methylated species of As such as DMA and MMA but at a much slower rate than inorganic forms of As [9]. Probably because of this, rice grains can accumulate a higher level of inorganic forms of As than organic As [43].

In rice, inorganic and organic As species differ in their mobility from root to shoot. Once, As is taken up by roots, As (V) is reduced to As (III) inside the plant tissues; As (III) is sequestered into root vacuoles or is translocated to the shoots and later disseminated to various organs [44]. In the mobility of As, nodes act as a controlling point, which regulates the As storage and its distribution to the rice grain. However, there is a lot to know about As transport and loading in rice [45]. Phosphorous applications found to have both synergistic and antagonistic impacts on the solubility and bioavailability of As in the soil, which is reported to be mainly dependent on the application concentration of P. Literature reports demonstrated that at low and high phosphorous application concentration, phosphorous may causes phytotoxicity in plants [44]. The excess addition of phosphorousto the arsenic contaminated soil is supposed to enhance the arsenic uptake by rice, Brassica juncea L. and Pteris vittata [46]. On the contrary, under phosphorous -deficient condition, As adversely effects on the cellular metabolisms due to low pools of phosphorylated primary metabolites and generate toxicity through the replacement of phosphorous from the ATP to form ADPAs [29]. In rice, the accumulated phosphorous influenced the cellular $\mathrm{pH}$, and limits the conversion of $\mathrm{As}(\mathrm{V})$ to As (III), and thus lowered the formation of ROS [19]. These observations indicate that the external phosphorous application amount including internal phosphorous level are the critical determinants of As accumulation in the rice. Thus, the optimal application of phosphorous in the root zone is essential for mitigation of As accumulation and its allied toxicity development in plants.

Generally, under stress conditions, both enzymatic and non-enzymatic defense systems of the plants become hyperactive [1]. Antioxidant metabolites such as phenolics help plants to adapt different environmental conditions and in providing protection against 
oxidative stress [2]. Previous studies demonstrated that As exposure triggers the synthesis of phenolic acids and flavonoids in plants $[1,47]$. Phenolics act as an antioxidant in plant systems and scavenge ROS, detoxify $\mathrm{H}_{2} \mathrm{O}_{2}$ by donating electrons to guaiacol-type peroxidases [47]. In general, the antioxidant capacity of phenolic compounds is in the order of unsubstituted phenol $<$ monophenols $<$ diphenols $<$ polyphenols [48]. In plants, flavonoids are reported to have lipid peroxidation inhibitory ability [49]. Herein, we estimated 18 phenolic acids and flavonoids in the rice grain samples in control and different treatment groups. Our results showed that the levels of TFA, CGA CA, and API7G were significantly increased in T0 group upon As exposure, which indicates their protective role in mitigating As-associated oxidative stress. Similar to our findings, As stress was reported to induce the TFA level in rice roots [46]. Moreover, intense accumulation of CA and CGA in Ulmus laevis Pall leaves is also reported under As stress, especially As (V) [2]. Results of this study also showed a moderate positive correlation with As (V). The lower amount of $\mathrm{P}$ application $\left(\leq 20 \mathrm{mg} \mathrm{kg}^{-1}\right)$ significantly increased the levels of SA, HES and RUT, indicating P application influenced the levels of the different phenolic acids and flavonoids of rice grain than those trigged by As exposure alone. Altogether, these findings indicated that TFA, CGA CA and API7G are accumulated in rice grain in response to As stress, and SA can be used as potent marker to distinguish inorganic and organic As species accumulation in rice grain. Moreover, results of present study also indicate the possibility of the production of certain phenolic acid and flavonoid compounds in rice is triggered in response to internal As level, rather than the accumulation of phosphorous. These specific compounds could be useful as biomarkers in breeding programs for developing low As accumulating rice, especially if As dependent increase is detected in vegetative tissues at earlier growth stage, allowing for large scale seedling screening.

\section{Materials and Methods}

\subsection{Chemicals and Reagents}

Authentic standards of phenolic acids (GA, 4-BA, CA, TFA, $p$-CA, VA, and SA), and flavonoids (API7G, HES, kaempferol (KAM), luteolin (LUT), myricetin (MYR), naringenin (NA), quercetin $(\mathrm{QE})$, and RUT) were procured from Sigma-Aldrich, India. The rice flour reference material (NIST1568b) and ammonium formate were also purchased from SigmaAldrich, India. Disodium methyl arsonate hexahydrate and dimethylarsinic acid were obtained from Chem Service inc, West Chester, PA, USA. Phenolic acids, CGA and PA, were purchased from HWI Analytik, GmbH, Germany. Apigenin (API) was obtained from Fluka (India). Ultrapure water (resistivity $18.2 \mathrm{M} \Omega-\mathrm{cm}$ ) was obtained from an ultra-pure Lab $\mathrm{Q}$ water purification system (Indion Lab $\mathrm{Q}$, India) and used throughout the experiment. Nitric acid $\left(65 \%-69 \%\right.$, TraceMetal ${ }^{\mathrm{TM}}$ Grade) and hydrochloric acid $\left(35 \%-37 \%\right.$, TraceMetal ${ }^{\mathrm{TM}}$ Grade) were purchased from Fisher, India. Standards of arsenic species, As (III) and As (V) were purchased from Supelco, India. Sodium arsenate, potassium dihydrogen phosphate, urea, and potassium chloride were procured from Merck, India. All other chemicals used were of analytical grade.

\subsection{Net House Experimentation}

Healthy paddy (Oryza sativa L., variety HUR-105) seedlings were transplanted to cylindrical polythene lined non-perforated earthen pots (diameter $30 \mathrm{~cm}$, height $25 \mathrm{~cm}$ ) containing $10 \mathrm{~kg}$ of alluvial soil. The pots were kept flooded, maintaining $4-5 \mathrm{~cm}$ of water above the soil surface, and the experiment was carried out up to four months still the harvesting phase of rice. The base soil level of As and phosphorous were $35 \mu \mathrm{g} \mathrm{Kg}^{-1}$ and $10.3 \mathrm{mg} \mathrm{Kg}^{-1}$, respectively and the molar ratio of phosphorous / As was 702.5 (Supplementary Table S1). The pots were placed in a net house, and during the growth period, the mean temperature, evaporation, sunshine hours, relative humidity, and wind speed were $26.13^{\circ} \mathrm{C}, 2.92 \mathrm{~mm}$, $6.29 \mathrm{~h}, 87.99 \%$, and $2.75 \mathrm{Km} \mathrm{h}^{-1}$, respectively. For the experiment, six groups consisting control (C) and five P treatments (T0-T4) were formed as follows; (1) C-no added As and P; (2) T0only treated with $10 \mathrm{mg} \mathrm{kg}^{-1}$ As (dose was selected based on literature reports [50,51] 
and preliminary observation); (3) T1-treated with $10 \mathrm{mg} \mathrm{kg}^{-1} \mathrm{As}$ and $10 \mathrm{mg} \mathrm{kg}^{-1} \mathrm{P}$; (4) T2treated with $10 \mathrm{mg} \mathrm{kg}^{-1}$ As and $20 \mathrm{mg} \mathrm{kg}^{-1} \mathrm{P}$; (5) T3-treated with $10 \mathrm{mg} \mathrm{kg}^{-1}$ As and $30 \mathrm{mg} \mathrm{kg}^{-1} \mathrm{P}$; and (6) T4-treated with $10 \mathrm{mg} \mathrm{kg}^{-1} \mathrm{As}$ and $40 \mathrm{mg} \mathrm{kg}^{-1} \mathrm{P}$. The calculated amount of As and $\mathrm{P}$ were applied as solutions of sodium arsenate $\left(\mathrm{Na}_{2} \mathrm{HAsO}_{4}, 7 \mathrm{H}_{2} \mathrm{O}\right)$ and potassium dihydrogen phosphate $\left(\mathrm{KH}_{2} \mathrm{PO}_{4}\right)$, respectively. Along with these, $53 \mathrm{mg}$ nitrogen in the form of urea $\left(\mathrm{CO}\left(\mathrm{NH}_{2}\right)_{2}\right)$ in three split and $44 \mathrm{mg}$ potassium in the form of $\mathrm{KCl}$ per $\mathrm{kg}$ of soil were applied to meet the main nutritional requirement of paddy.

\subsection{Measurement of Agronomic Parameters and Phosphorus Estimation}

Rice plants were harvested by cutting at $5 \mathrm{~cm}$ above the soil (to avoid basal tissue contamination by applied arsenate solution). The mass of filled spikelets (i.e., grain including husk) per pot (grain yield) was recorded after freeze-drying the spikelets. Rice grains were separated from their husks using metal-free dehusker, and then grains were ground using mortar and pestle. The straw biomass (defined as the remaining aboveground portion of the rice plant after the spikelets have been removed) was recorded per pot after drying at $65^{\circ} \mathrm{C}$ for $72 \mathrm{~h}$. Roots were separated from the soil very carefully using water, and the weight of root biomass per pot was recorded after drying at $65^{\circ} \mathrm{C}$ for $72 \mathrm{~h}$. The total chlorophyll contents in the rice leaf samples were estimated using the method described by Hiscox [52]. Phosphorus estimation in rice grain samples was performed as per the protocol described by Jackson [53].

\subsection{LC-ICP-MS Analysis of Arsenic Species}

Rice grain samples were ground into a fine powder using mortar and pestle and sieved through $355 \mu \mathrm{m}$ (No. 45 ASTM E11) sieve prior to use. Weighed $200 \mathrm{mg}$ powder of each sample and transferred into $50 \mathrm{~mL}$ of polypropylene digesting tube for digestion. An aliquot of $10 \mathrm{~mL}$ of $1 \%$ ultrapure nitric acid was added to the polypropylene tubes containing the samples. The mixture was allowed to stand overnight. Samples were digested in a microwave-accelerated reaction system (Anton Paar, Graz, Austria) using a set program in our laboratory as follows: the temperature was gently raised, first to $55{ }^{\circ} \mathrm{C}$ and then to $75{ }^{\circ} \mathrm{C}$, with holding time of $10 \mathrm{~min}$. Finally, the digestion was done at $95{ }^{\circ} \mathrm{C}$ with holding time for $30 \mathrm{~min}$. Upon reaching room temperature, samples were centrifuged at $3214 \times g$ at $4{ }^{\circ} \mathrm{C}$ for 5 min using Beckman Coulter Allegra X-30R Centrifuge. The supernatant was collected and again centrifuged at $7168 \times g$ at $4{ }^{\circ} \mathrm{C}$ for $15 \mathrm{~min}$. Samples were kept in the dark on the ice to minimize species transformation until analysis [54]. NIST reference material of rice flour was used to validate the analyses. An aliquot of $50 \mu \mathrm{L}$ was injected into the Agilent G5654A 1260 HPLC-coupled to an Agilent G8421A ICP-MS. For As speciation, the Agilent ZORBAX SB-Aq $(4.6 \mathrm{~mm}$ id $\times 250 \mathrm{~mm}, 5 \mu \mathrm{m})$ reverse phase column was used and maintained at room temperature throughout the analysis. An isocratic mobile phase containing $20 \mathrm{mM}$ citric acid and $5 \mathrm{mM}$ sodium hexane sulphonate, pH 4.3 was used for As species separation. Collision/reaction cell (CRC) mode was used to reduce the polyatomic interference of chloride $(\mathrm{Ar} 35 \mathrm{Cl}+)$ in the quantification of $75 \mathrm{As}$.

\subsection{LC-MS/MS Analysis of Phenolic Acids and Flavonoids}

Phenolic acids and flavonoids (soluble-free and -conjugated) were extracted in $80 \%$ methanol [55]. Briefly, $1 \mathrm{~mL}$ of $80 \%$ methanol was added into the microcentrifuge tube containing $50 \mathrm{mg}$ rice flour sample. All tubes were vortexed and sonicated for $10 \mathrm{~min}$ and then centrifuged at $10,000 \times g$ for $10 \mathrm{~min}$ at $7^{\circ} \mathrm{C}$. Approximately $\sim 800 \mu \mathrm{L}$ of supernatant was collected into fresh microcentrifuge tubes, and 1 of $\mathrm{mL} 80 \%$ methanol was added to the residue, followed by the same extraction procedure. The supernatant was again collected in each tube $(\sim 1.6 \mathrm{~mL})$ and finally centrifuged at $10,000 \times \mathrm{g}$ for $10 \mathrm{~min}$ at $7{ }^{\circ} \mathrm{C}$, and transferred to LC vials for quantitative analysis. Both phenolic acids and flavonoids were analyzed using Agilent 6470 triple-quadrupole mass spectrometer coupled with 1260 Infinity II Prime LC. The separation was carried out on Pursuit 3 PFP $(3 \mu \mathrm{m}, 150 \times 2 \mathrm{~mm})$ column at the flow rate of $0.43 \mathrm{~mL} \mathrm{~min}^{-1}$ using the gradient mobile phase, $0.1 \%$ aqueous 
formic acid containing $5 \mathrm{mM}$ ammonium formate (A) and $0.1 \%$ formic acid in methanol (B). The gradient program for pump B was as follows: $0.0-0.5 \mathrm{~min}, 2.0 \%$; $0.5-5.0 \mathrm{~min}, 50 \%$; $5.0-12.0 \mathrm{~min}, 98 \%$; $12.0-12.1 \mathrm{~min}, 2 \%$; and $12.1-15.0 \mathrm{~min}, 2 \%$. The column temperature was set at $40{ }^{\circ} \mathrm{C}$. The mass spectra were acquired in both positive and negative modes using Jet Stream Electrospray Ionization, and quantification of all analytes were carried out in MRM mode. The mass spectrometer was operated under the following conditions: nebulizer gas pressure, $40 \mathrm{bar}$, nebulizer gas flow, $10 \mathrm{~L} \mathrm{~min}^{-1}$, gas temperature, $300{ }^{\circ} \mathrm{C}$; sheath gas heater temperature, $250^{\circ} \mathrm{C}$, sheath gas flow, $11 \mathrm{~L} \mathrm{~min}^{-1}$, capillary voltage, $4500 \mathrm{~V}$ and charging voltage, $500 \mathrm{~V}$. Mass Hunter workstation software (Agilent Technologies, USA) was used to control the instruments as well as to acquire and process the data.

\subsection{Statistics}

Results were expressed as a mean \pm standard error (SE) of three biological and two technical replicates per sample. SPSS 16.0 was used to conduct one-way ANOVA followed by the post hoc Duncan's Multiple Range Test (DMRT). XLSTAT (Addinsoft, 2020) and MetaboAnalyst 3.0 (http:/ / www.metaboanalyst.ca/) software were used for multivariate analysis [56].

\section{Conclusions}

Herein, we have demonstrated that the optimal use of $\mathrm{P}$ in the soil has a considerable impact on the accumulation of As species and allied toxicity in rice grown under As spiked soil. The findings of this study indicated that the $P$ treatment of concentration $30 \mathrm{mg} \mathrm{kg}^{-1}$ was optimal to minimize As linked toxicity on agronomic parameters and chlorophyll biosynthesis, and enhance the safety of rice grain for consumption. Furthermore, TFA, CGA, $\mathrm{CA}$, and API7G were found to deposit in response to accumulation As in rice grain. These phenolic metabolites can be used as biomarkers in low arsenic rice breeding programs to screen out As tolerant seedlings, provided the As dependent increase in these compounds are confirmed in vegetative tissues at the earlier growth period of rice. Moreover, SA can be a potent marker to distinguish inorganic and organic As species accumulation in rice grain. Further studies are envisaged to confirm the expression of these biomarkers at the early vegetative phase of rice growth under As stress conditions. Taken together, this study shows that the precise use of P may help to mitigate arsenic phytotoxicity and enhance the food safety aspect of rice grains.

Supplementary Materials: The following are available online at https:/ / www.mdpi.com/2223-774 7/10/2/281/s1, Table S1: Physical, chemical and biological properties of initial soil.

Author Contributions: Conceptualization, A.C., A.P.S., and D.K.; methodology, A.C., D.K., and I.S.; software, A.C., D.K.; validation, D.K. and I.S.; formal analysis, A.C.; investigation, A.C.; resources, A.R. and A.P.S.; data writing, original draft preparation, A.C. and D.K.; writing, review and editing, D.K. and A.R.; visualization, A.C. and D.K.; supervision, A.P.S. and D.K.; funding acquisition, A.R. Both A.C. and D.K. are contributed equally to the manuscript. All authors have read and agreed to the published version of the manuscript.

Funding: This work is supported by IRRI South Asia Regional Centre, established in 2018 with the financial support of the Government of India and IRRI. A.C. received financial assistance from the Department of Science \& Technology (DST), Ministry of Science and Technology, Government of India, to pursue doctoral degree (grant number DST/INSPIRE Fellowship/IF160796IT14908).

Institutional Review Board Statement: Not applicable.

Informed Consent Statement: Not applicable.

Data Availability Statement: The data presented in this study are available on request from the corresponding author.

Acknowledgments: A.C. acknowledges the International Rice Research Institute (IRRI), South Asia Regional Centre (Varanasi, India), for providing sophisticated instrumental facilities to contact research.

Conflicts of Interest: The authors declare no conflict of interest. 


\section{References}

1. Abbas, G.; Murtaza, B.; Bibi, I.; Shahid, M.; Niazi, N.K.; Khan, M.I.; Amjad, M.; Hussain, M. Arsenic uptake, toxicity, detoxification, and speciation in plants: Physiological, biochemical, and molecular aspects. Int. J. Environ. Res. Health 2018, 15, 59. [CrossRef] [PubMed]

2. Drzewiecka, K.; Gąsecka, M.; Rutkowski, P.; Magdziak, Z.; Goliński, P.; Mleczek, M. Arsenic forms and their combinations induce differences in phenolic accumulation in Ulmus laevis Pall. J. Plant Physiol. 2018, 220, 34-42. [CrossRef] [PubMed]

3. Akinbile, C.O.; Haque, A. Arsenic contamination in irrigation water for rice production in Bangladesh: A review. Trends Appl. Sci. Res. 2012, 7, 331. [CrossRef]

4. Li, J.; Yoshi, S.; Hashimoto, Y.; Wang, L.; Wang, F.; Riya, S.; Terada, A.; Hosomi, M. Reducing geogenic arsenic leaching from excavated sedimentary soil using zero-valent iron amendment followed by dry magnetic separation: A case study. Sci. Total Environ. 2020, 724, 138203. [CrossRef] [PubMed]

5. Ye, Y.; Li, P.; Xu, T.; Zeng, L.; Cheng, D.; Yang, M.; Luo, J.; Lian, X. OsPT4 contributes to arsenate uptake and transport in rice. Front. Plant Sci. 2017, 8, 2197. [CrossRef]

6. Chattopadhyay, A.; Singh, A.P.; Singh, S.K.; Barman, A.; Patra, A.; Mondal, B.P.; Banerjee, K. Spatial variability of arsenic in Indo-Gangetic basin of Varanasi and its cancer risk assessment. Chemosphere 2020, 238, 124623. [CrossRef]

7. Finnegan, P.; Chen, W. Arsenic toxicity: The effects on plant metabolism. Front. Physiol. 2012, 3, 182. [CrossRef]

8. Carey, A.-M.; Scheckel, K.G.; Lombi, E.; Newville, M.; Choi, Y.; Norton, G.J.; Charnock, J.M.; Feldmann, J.; Price, A.H.; Meharg, A.A. Grain unloading of arsenic species in rice. Plant Physiol. 2010, 152, 309-319. [CrossRef]

9. Meharg, A.A.; Zhao, F.-J. Arsenic E Rice; Springer Science \& Business Media: Berlin, Germany, 2012.

10. Abedin, M.J.; Cresser, M.S.; Meharg, A.A.; Feldmann, J.; Cotter-Howells, J. Arsenic accumulation and metabolism in rice (Oryza sativa L.). Environ. Sci. Technol. 2002, 36, 962-968. [CrossRef]

11. Abedin, M.J.; Feldmann, J.; Meharg, A.A. Uptake kinetics of arsenic species in rice plants. Plant Physiol. 2002, 128, 1120-1128. [CrossRef]

12. Ma, J.F.; Yamaji, N.; Mitani, N.; Xu, X.-Y.; Su, Y.-H.; McGrath, S.P.; Zhao, F.-J. Transporters of arsenite in rice and their role in arsenic accumulation in rice grain. Proc. Natl. Acad. Sci. USA 2008, 105, 9931-9935. [CrossRef] [PubMed]

13. Matsumoto, S.; Kasuga, J.; Makino, T.; Arao, T. Evaluation of the effects of application of iron materials on the accumulation and speciation of arsenic in rice grain grown on uncontaminated soil with relatively high levels of arsenic. Environ. Exp. Bot. 2016, 125, 42-51. [CrossRef]

14. Meharg, A.A.; Hartley-Whitaker, J. Arsenic uptake and metabolism in arsenic resistant and nonresistant plant species. New Phytol. 2002, 154, 29-43. [CrossRef]

15. Mirza, N.; Mahmood, Q.; Maroof Shah, M.; Pervez, A.; Sultan, S. Plants as useful vectors to reduce environmental toxic arsenic content. Sci. World J. 2014, 2014, 921581. [CrossRef]

16. Mallick, S.; Sinam, G.; Sinha, S. Study on arsenate tolerant and sensitive cultivars of Zea mays L.: Differential detoxification mechanism and effect on nutrients status. Ecotoxicol. Environ. Saf. 2011, 74, 1316-1324. [CrossRef]

17. Suriyagoda, L.D.; Dittert, K.; Lambers, H. Arsenic in Rice soils and potential agronomic mitigation strategies to reduce arsenic bioavailability: A review. Pedosphere 2018, 28, 363-382. [CrossRef]

18. Gunes, A.; Pilbeam, D.J.; Inal, A. Effect of arsenic-phosphorus interaction on arsenic-induced oxidative stress in chickpea plants. Plant Soil 2009, 314, 211-220. [CrossRef]

19. Choudhury, B.; Chowdhury, S.; Biswas, A.K. Regulation of growth and metabolism in rice (Oryza sativa L.) by arsenic and its possible reversal by phosphate. J. Plant Interact. 2011, 6, 15-24. [CrossRef]

20. Srivastava, S.; Sharma, Y. Arsenic phytotoxicity in black gram (Vigna mungo L. Var. PU19) and its possible amelioration by phosphate application. J. Plant Physiol. Pathol. 2013, 3, 2.

21. Kasote, D.M.; Katyare, S.S.; Hegde, M.V.; Bae, H. Significance of antioxidant potential of plants and its relevance to therapeutic applications. Int. J. Biol. Sci. 2015, 11, 982. [CrossRef]

22. Dave, R. In vitro models for antioxidant activity evaluation and some medicinal plants possessing antioxidant properties: An overview. Afr. J. Microbiol. Res. 2009, 3, 981-996.

23. Rahman, A.; Mostofa, M.G.; Alam, M.; Nahar, K.; Hasanuzzaman, M.; Fujita, M. Calcium mitigates arsenic toxicity in rice seedlings by reducing arsenic uptake and modulating the antioxidant defense and glyoxalase systems and stress markers. Biomed. Res. Int. 2015, 2015, 340812. [CrossRef] [PubMed]

24. Magdziak, Z.; Gasecka, M.; Budka, A.; Goliński, P.; Mleczek, M. Profile and concentration of the low molecular weight organic acids and phenolic compounds created by two-year-old Acer platanoides seedlings growing under different As forms. J. Hazard. Mater. 2020, 392, 122280. [CrossRef] [PubMed]

25. Deligios, P.A.; Rapposelli, E.; Mameli, M.G.; Baghino, L.; Mallica, G.M.; Ledda, L. Effects of Physical, Mechanical and Hormonal Treatments of Seed-Tubers on Bud Dormancy and Plant Productivity. Agronomy 2020, 10, 33. [CrossRef]

26. Lee, J.H.; Jayaprakasha, G.; Rush, C.M.; Crosby, K.M.; Patil, B.S. Production system influences volatile biomarkers in tomato. Metabolomics 2018, 14, 99. [CrossRef]

27. Chandrakar, V.; Naithani, S.C.; Keshavkant, S. Arsenic-induced metabolic disturbances and their mitigation mechanisms in crop plants: A review. Biologia 2016, 71, 367-377. [CrossRef] 
28. Lihong, W.; Guilan, D. Effect of external and internal phosphate status on arsenic toxicity and accumulation in rice seedlings. J. Environ. Sci. 2009, 21, 346-351.

29. Zvobgo, G.; LwalabaWaLwalaba, J.; Sagonda, T.; Mapodzeke, J.M.; Muhammad, N.; Shamsi, I.H.; Zhang, G. Phosphate alleviates arsenate toxicity by altering expression of phosphate transporters in the tolerant barley genotypes. Ecotoxicol. Environ. Saf. 2018, 147, 832-839. [CrossRef]

30. Zeng, X.; Wu, P.; Su, S.; Bai, L.; Feng, Q. Phosphate has a differential influence on arsenate adsorption by soils with different properties. Plant Soil Environ. 2012, 58, 405-411. [CrossRef]

31. Kumar, N.; Mallick, S.; Yadava, R.N.; Singh, A.P.; Sinha, S. Co-application of selenite and phosphate reduces arsenite uptake in hydroponically grown rice seedlings: Toxicity and defence mechanism. Ecotoxicol. Environ. Saf. 2013, 91, 171-179. [CrossRef]

32. Lee, C.H.; Wu, C.H.; Syu, C.H.; Jiang, P.Y.; Huang, C.C.; Lee, D.Y. Effects of phosphorous application on arsenic toxicity to and uptake by rice seedlings in As-contaminated paddy soils. Geoderma 2016, 270, 60-67. [CrossRef]

33. Miteva, E.; Merakchiyska, M. Response of chloroplasts and photosynthetic mechanism of bean plants to excess arsenic in soil. Bulg. J. Agric. Sci. 2009, 8, 151-156.

34. Mishra, S.; Alfeld, M.; Sobotka, R.; Andresen, E.; Falkenberg, G.; Küpper, H. Analysis of sublethal arsenic toxicity to Ceratophyllum demersum: Subcellular distribution of arsenic and inhibition of chlorophyll biosynthesis. J. Exp. Bot. 2016, 67, 4639-4646. [CrossRef] [PubMed]

35. Terry, M.J.; Smith, A.G. A model for tetrapyrrole synthesis as the primary mechanism for plastid-to-nucleus signaling during chloroplast biogenesis. Front. Plant Sci. 2013, 4, 14. [CrossRef]

36. Uroic, K.; Salaun, P.; Raab, A.; Feldmann, J. Arsenate impact on the metabolite profile, production, and arsenic loading of xylem sap in cucumbers (Cucumis sativus L.). Front. Physiol. 2012, 3, 55. [CrossRef]

37. Hossain, M.B.; Jahiruddin, M.; Loeppert, R.; Panaullah, G.; Islam, M.; Duxbury, J. The effects of iron plaque and phosphorus on yield and arsenic accumulation in rice. Plant Soil 2009, 317, 167-176. [CrossRef]

38. Majumder, B.; Das, S.; Pal, B.; Biswas, A.K. Evaluation of arsenic induced toxicity based on arsenic accumulation, translocation and its implications on physio-chemical changes and genomic instability in indica rice (Oryza sativa L.) cultivars. Ecotoxicology 2020, 29, 13-34. [CrossRef]

39. Choudhury, B.; Mitra, S.; Biswas, A.K. Regulation of sugar metabolism in rice (Oryza sativa L.) seedlings under arsenate toxicity and its improvement by phosphate. Physiol. Mol. Biol. Plants 2010, 16, 59-68. [CrossRef]

40. Chao, D.-Y.; Chen, Y.; Chen, J.; Shi, S.; Chen, Z.; Wang, C.; Danku, J.M.; Zhao, F.-J.; Salt, D.E. Genome-wide association mapping identifies a new arsenate reductase enzyme critical for limiting arsenic accumulation in plants. PLoS Biol. 2014, 12, e1002009. [CrossRef]

41. Li, R.-Y.; Ago, Y.; Liu, W.-J.; Mitani, N.; Feldmann, J.; McGrath, S.P.; Ma, J.F.; Zhao, F.-J. The rice aquaporin Lsi1 mediates uptake of methylated arsenic species. Plant Physiol. 2009, 150, 2071-2080. [CrossRef]

42. Geng, C.-N.; Zhu, Y.-G.; Liu, W.-J.; Smith, S.E. Arsenate uptake and translocation in seedlings of two genotypes of rice is affected by external phosphate concentrations. Aquat. Bot. 2005, 83, 321-331. [CrossRef]

43. Zheng, M.-Z.; Li, G.; Sun, G.-X.; Shim, H.; Cai, C. Differential toxicity and accumulation of inorganic and methylated arsenic in rice. Plant Soil 2013, 365, 227-238. [CrossRef]

44. Mitra, A.; Chatterjee, S.; Moogouei, R.; Gupta, D.K. Arsenic accumulation in rice and probable mitigation approaches: A review. Agronomy 2017, 7, 67. [CrossRef]

45. Awasthi, S.; Chauhan, R.; Srivastava, S.; Tripathi, R.D. The journey of arsenic from soil to grain in rice. Front. Plant Sci. 2017, 8, 1007. [CrossRef]

46. Bolan, N.; Mahimairaja, S.; Kunhikrishnan, A.; Choppala, G. Phosphorus-arsenic interactions in variable-charge soils in relation to arsenic mobility and bioavailability. Sci. Total Environ. 2013, 463, 1154-1162. [CrossRef]

47. Sakihama, Y.; Cohen, M.F.; Grace, S.C.; Yamasaki, H. Plant phenolic antioxidant and prooxidant activities: Phenolics-induced oxidative damage mediated by metals in plants. Toxicology 2002, 177, 67-80. [CrossRef]

48. Gülcin, I. Antioxidant activity of food constituents: An overview. Arch. Toxicol. 2012, 86, 345-391. [CrossRef]

49. Kaurinovic, B.; Vastag, D. Flavonoids and phenolic acids as potential natural antioxidants. In Antioxidants; IntechOpen: London, UK, 2019.

50. Shrivastava, A.; Ghosh, D.; Dash, A.; Bose, S. Arsenic contamination in soil and sediment inIndia: Sources, effects, and remediation. Curr. Pollut. Rep. 2015, 1, 35-46. [CrossRef]

51. Singh, H.P.; Kaur, S.; Batish, D.R.; Sharma, V.P.; Sharma, N.; Kohli, R.K. Nitric oxide alleviates arsenic toxicity by reducing oxidative damage in the roots of Oryza sativa (rice). Nitric Oxide 2009, 20, 289-297. [CrossRef]

52. Hiscox, J.; Israelstam, G. A method for the extraction of chlorophyll from leaf tissue without maceration. Can. J. Bot. 1979, 57, 1332-1334. [CrossRef]

53. Jackson, M. Soil Chemical Analysis Prentice; Hall of India Private Limited: New Delhi, India, 1967.

54. Zhu, Y.-G.; Sun, G.-X.; Lei, M.; Teng, M.; Liu, Y.-X.; Chen, N.-C.; Wang, L.-H.; Carey, A.; Deacon, C.; Raab, A. High percentage inorgaic arsenic content of mining impacted and nonimpacted Chinese rice. Environ. Sci. Technol. 2008, 42, 5008-5013. [CrossRef] [PubMed] 
55. Shao, Y.; Hu, Z.; Yu, Y.; Mou, R.; Zhu, Z.; Beta, T. Phenolic acids, anthocyanins, proanthocyanidins, antioxidant activity, minerals and their correlations in non-pigmented, red, and black rice. Food Chem. 2018, 239, 733-741. [CrossRef] [PubMed]

56. Xia, J.; Wishart, D.S. Using MetaboAnalyst 3.0 for comprehensive metabolomics data analysis. Curr. Protoc. Bioinform. 2016, 55, 14.10.1-14.10.91. [CrossRef] [PubMed] 